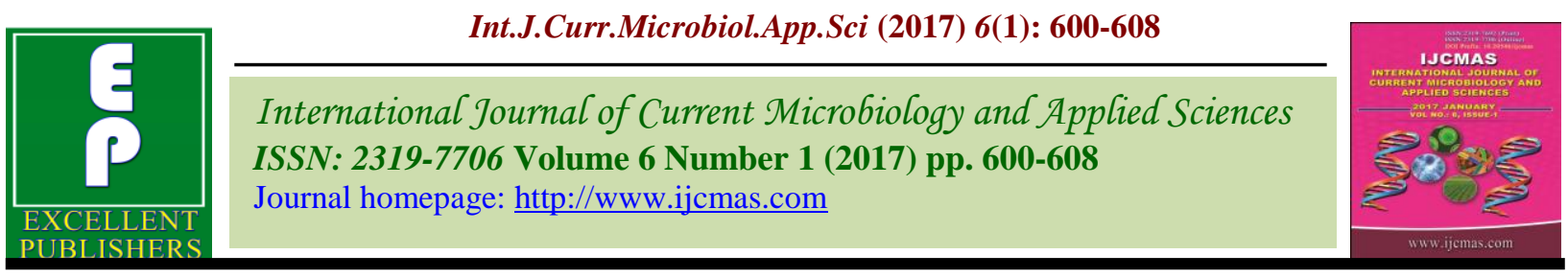

Original Research Article http://dx.doi.org/10.20546/ijcmas.2017.601.073

\title{
Phytochemical Screening and Antimicrobial Activity of Various Extracts of Salvia aegyptiaca L.
}

\author{
H. Pratima* and Veenashri Policepatil \\ Department of Post-Graduate Studies and Research in Botany, Karnataka State Women's \\ University Vijayapura, Karnataka, India \\ *Corresponding author
}

\section{A B S T R A C T}

\section{Keywords}

Agar well diffusion method, antimicrobial activity, crude extract, phytochemicals,

Salvia aegyptiaca.

Article Info

Accepted:

29 December 2016

Available Online:

10 January 2017
The present study was conducted to asses phytochemical and antibacterial activity of various crude extracts viz, pet-ether, chloroform, methanol and aqueous extracts of Salvia aegyptiaca against bacteria and fungi such as Staphylococcus aureus (MTCC Code 9886), Pseudomonas aeruginosa (MTCC Code - 6458), Aspergillus niger (MTCC Code 872), Aspergillus flavus (MTCC Code - 8790) by adapting agar well diffusion method. The highest percentage of extraction yield was observed in aqueous extract followed by methanol, chloroform and petether extracts. The phytochemical test revealed that the presence of proteins, carbohydrates, lipids, alkaloids, phenols, flavonoids, steroids, glycosides, tannins, terpenoids and resins. The crude extracts of Salvia aegyptiaca have displayed significant to moderate and dose dependent $(25,50$ and $100 \mathrm{mg} / \mathrm{ml})$ antibacterial and antifungal activity. The antibacterial activity of methanol extract shows maximum inhibition zone on Gram positive bacteria Staphylococcus aureus compared to Gram negative bacteria Pseudomonas aeruginosa at $100 \mathrm{mg} / \mathrm{ml}$ concentration. Similarly, the antifungal activity of aqueous extract shows maximum inhibition zone on Aspergillus flavus compared to Aspergillus niger at $100 \mathrm{mg} / \mathrm{ml}$ concentration. Overall, fungi were more sensitive than the bacterial strains in Salvia aegyptiaca.

\section{Introduction}

Medicinal plants are rich source of metabolites that are potential sources of drugs and essential oils. Clinical microbiologists have great interest in screening of medicinal plants for antimicrobial activities and phytochemicals as potential new therapeutics. The antimicrobial properties of plants have been investigated by a number of researchers worldwide though biological evaluation of plants extracts is vital to ensure their efficacy and safety. These factors are of importance if plant extracts are to be accepted as valid medical agents for the treatment of infectious diseases (Tanaka et al., 2006) especially in light of the emergence of drug-resistant microorganisms. Despite the medicinal potential of plants being considerable in our country, knowledge and studies on wild growing Salvia species from this area are scarce; accounts for their therapeutic effects were found especially in other sources (Bagci and Koçaka, 2007; Tepe et al., 2007).

Saliva aegyptiaca L. (Egyptian sage) is belongs to Lamiaceae family. It is a green dwarf shrub that grows in various locations in 
the world and commonly used in folk medicine. The seeds of the plant are used as demulcent for piles, and whole plant is used in diarrhea, gonorrhea and hemorrhoids, eye diseases and as an antiseptic, antispasmodic and stomachic (Rizk and El-Ghazaly, 1995). The plant is also used in cases of nervous disorders, dizziness and trembling and stopping perspiration (Al Yousuf et al., 2002). Salem (2004) has isolated some terpenoids and fatty acid esters from the nonvolatile matter of $S$. aegyptiaca. The extracts of higher plants can be very good source of antibiotics (Firdous et al., 1990) against various bacterial and fungal pathogens. The antimicrobial activities of Salvia species was reported by many researchers (Omidreza Firuzi et al., 2013; Nurcan Erbil and Metin Digrak, 2015; Ali and Aboud, 2010).

Due to its ethnomedicinal importance it is evident from the available literature that the search for crude drugs of plant origin with phytochemical and antimicrobial studies has become a central focus of research.

The main aim of the present study was to evaluate the phytochemical and antimicrobial activity against various pathogenic bacteria and fungi in whole plant crude extracts of Salvia aegyptiaca.

Extractive value $(\%)=$ Weight of the residue obtained $\times 100$

Weight of the plant material taken

\section{Preliminary screening test for Phytochemicals}

The preliminary test for the detection of the primary and secondary metabolites were carried out for all the extracts of Salvia aegyptiaca were separately tested by the standard methods (Harborne, 1998; Gibbs, 1974; Sadasivam and Manickam, 1992.)

\section{Material and Methods}

\section{Collection of Plant Materials}

Salvia aegyptiaca (Lamiaceae) plant was collected in the month of September 2015 from campus of Karnataka state women's university, Vijayapura, India. The plant was identified with the help of flora 'The Presidency of Bombay' (Cooke, 1906). The voucher specimen has been deposited in the department of Botany, Karnataka state women's university, Vijayapura. The whole plant was dried in the shade at room temperature between $25-30^{\circ} \mathrm{C}$ for $15-30$ days, after drying the plant were chopped and grinded made into fine powder.

\section{Preparation of Crude extracts}

The 20gm of the powdered material was separately soaked in volumetric flask containing $100 \mathrm{ml}$ of different solvents of petroleum ether, chloroform, methanol, and aqueous for $24 \mathrm{hr}$ with occasional shaking. The extracts were filtered using Whatsman No.1 filter paper. The resulting liquid extracts were evaporated to dryness under reduced pressure. The plant extracts were stored in a clean sterile container for further use. The yields of the extracts were calculated using the following formula (Raghnathan, 1976; Usha Shome, et al., 1984).

\section{Test for proteins}

Biuret test: $2 \mathrm{ml}$ of $10 \% \mathrm{NaOH}$ was added to $2 \mathrm{ml}$ of test solution, mixed well and 2 drops of $0.1 \%$ copper sulphate solution was added. Violet or pink colour indicates the presence of two or more peptide bonds of proteins.

Hopkins-Cole test: $2 \mathrm{ml}$ of glacial aectic acid was added $2 \mathrm{ml}$ of the test solution and mixed 
well. To this $2 \mathrm{ml}$ of conc. $\mathrm{H}_{2} \mathrm{SO}_{4}$ was added carefully along the sides of test tube. Formation of violet ring at the junction of the two liquids indicates the presence of indole group of tryptophan.

\section{Test for carbohydrates}

Molisch's reagent test: 2 drops of molisch's reagent was added to $2 \mathrm{ml}$ of test solution, mixed well. Inclined the tube and $1 \mathrm{ml}$ of conc. sulphuric acid were added along the sides of the test tube.

At the junction of the two liquids a red come violet coloured ring indicates the presence of carbohydrates.

Benedict's test: $2 \mathrm{ml}$ of Benedict's reagent was added to five drops of the test solution. Boiled for a minute in a water bath and cooled the solution. Yellow, red or green colour precipitate indicates the presence of reducing sugars.

Fehling's test: $1 \mathrm{ml}$ of Fehling's solution ' $\mathrm{A}$ ' and $1 \mathrm{ml}$ of Fehling's solution ' $\mathrm{B}$ ' were added to $1 \mathrm{ml}$ of test solution. The contents were mixed well and boiled for a minute. Yellow or brownish-red precipitate indicates the presence of reducing sugar.

\section{Test for lipids}

Stain test: Small quantity of extract was taken and pressed between to two whatsman No-1 filter paper. The stain on the filter paper indicates the presence of fixed oil.

Saponification test: To small quantity of various test solution and add few drops of $0.5 \mathrm{~N}$ alcoholic potassium hydroxide and a few drops of phenolphthalein indicator and heat on water bath for 1-2 hour presence of fixed oil and fats is indicated by the formation of soap.

\section{Tests for Alkaloids}

Mayer's test: $1 \mathrm{ml}$ of $\mathrm{KI}$ in iodine solution was added to the $2 \mathrm{ml}$ of test solution. A creamy white precipitate formation indicated the presence of alkaloids.

Dragendorff's reagent: $2 \mathrm{ml}$ of Dragendorff's reagent and $2 \mathrm{ml}$ of dilute $\mathrm{HCl}$ were added to the test solution. An orange-red coloured precipitate indicates the presence of alkaloids.

Wagner's test: $2 \mathrm{ml}$ of Wagner's reagent was added to $2 \mathrm{ml}$ of test solution. The formation of reddish brown precipitate indicates the presence of alkaloids.

\section{Tests for Phenols}

Ferric chloride test: $0.5 \mathrm{ml}$ of $\mathrm{FeCl}_{3}(\mathrm{w} / \mathrm{v})$ solution was added to $2 \mathrm{ml}$ of test solution, formation of an intense colour indicates the presence of phenols.

Ellagic acid test: The test solution was treated with few drops of $5 \%(\mathrm{v} / \mathrm{v})$ glacial acetic acid and $5 \%(\mathrm{w} / \mathrm{v}) \mathrm{NaNO}_{2}$ solution. The solution turns muddy yellow, olive brown, Niger brown, deep chocolate colours depending on the amount of ellagic acid present.

\section{Tests for Flavonoids}

Pew's test: A pinch of zinc powder and about 5 drops of $5 \mathrm{~N} \mathrm{HCl}$ were added to the test solution. It results deep purple red (dihydroquercetin) or cherry red (dihydrokaempferol) colours. Flavonones, dehydrochalcones and other flavonoids get at most pinkish or brownish colour.

Shinoda test: A pinch of magnesium powder and $5 \mathrm{~N} \mathrm{HCl}$ were added to the test solution and a deep red or magenta colour formation indicates the presence of flavanone or 
dihydroflavanol. However, dihydrocarchalcones and other flavonoids did not react with this reagent.

\section{Tests of steroid}

Salkowski's test: A wine red colour was developed when chloroform and Conc. $\mathrm{H}_{2} \mathrm{SO}_{4}$ were added to the test solution; indicate the presence of steroidal nucleus.

\section{Tests for glycosides}

Conc. $\mathrm{H}_{2} \mathrm{SO}_{4}$ test: To the extract add Conc. $\mathrm{H}_{2} \mathrm{SO}_{4}$ and allowed to stand for few minutes, it turned into reddish colour.

Kellar Killiani test: The extract was dissolved in glacial acetic acid and after cooling 2 drops of ferric chloride solution was added to it. These content were transferred to a test tube containing $2 \mathrm{ml}$ of Conc. $\mathrm{H}_{2} \mathrm{SO}_{4}$. A reddish brown ring was observed at the junction of two layers.

\section{Tests for tannins}

Gelatin test: To the extract add few drops of $1 \%$ gelatin solution containing $10 \% \mathrm{Nacl}_{2}, \mathrm{~A}$ white colour precipitate observed.

\section{Tests for terpenoids}

Conc. $\mathrm{H}_{2} \mathrm{SO}_{4}$ test: To the extract add few drops of glacial acetic acid and after cooling add $2 \mathrm{ml}$ of $\mathrm{H}_{2} \mathrm{SO}_{4}$ along the sides of the test tube. A reddish or brown or pinkish colour ring was observed at the junction of two layers.

\section{Test for saponins}

Foam test: $0.01 \mathrm{~g}$ of crude extract was shaken vigorously in $2 \mathrm{ml}$ of distilled water. Formation of honeycomb like froth persists for a few minutes indicate the presence of saponins.

\section{Test for Resins}

To the $1 \mathrm{ml}$ of the test solution, $2-3 \mathrm{ml}$ of copper sulphate solution was added, the contents was mixed well for 2 minutes and then the solution was allowed to separate resins were indicated green coloured precipitate.

\section{Antimicrobial Activity}

The in vitro antibacterial activity and antifungal activity of Salvia aegyptiaca L. crude extracts were carried out by adopting the agar well diffusion method.

\section{Preparation of crude extract for screening} assay

The crude extracts (pet-ether, chloroform, methanol, aqueous) were dissolved in dimethyl sulfoxide(DMSO) and the final concentrations of the crude extract solution were obtained as $25 \mathrm{mg} / \mathrm{ml}, 50 \mathrm{mg} / \mathrm{ml}$ and $100 \mathrm{mg} / \mathrm{ml}$ respectively

\section{Pathogens used}

The pure axenice culture of bacteria and fungi such as Staphylococcus aureus (MTCC Code - 9886), Pseuomonas aeruginosa (MTCC Code - 6458), Aspergillus niger (MTCC Code - 872), Aspergillus flavors (MTCC Code 8790) (Microbial type culture collection) were obtained from Institute of Microbial Technology, Chandigarh. All the Cultures were maintained on Nutrient Agar for further use.

\section{Antibacterial Activity}

The extracts were screened for their antibacterial activity in comparison with standard Streptomycin $(10 \mathrm{mg} / \mathrm{ml})$ in -vitro by agar well diffusion method (Indian Pharmocopia, 1996). The Petri plates containing $15-20 \mathrm{ml}$ of Muller Hinton Agar 
(MHA) medium was inoculated with $200 \mu \mathrm{L}$ of $18 \mathrm{~h}$ old bacterial culture was evenly spread with a sterile bent glass rod. The inoculated plates are kept aside for few minutes. A sterile cork borer was then used to make four wells (8mm diameter) for different concentrations of the extract, on each of the plates containing cultures of the different test organisms. The four peripheral wells were loaded with $100 \mu \mathrm{l}$ of pet ether, chloroform, methanol and aqueous plant extracts of the concentration 25,50 and $100 \mathrm{mg} / \mathrm{ml}$ respectively. In the similar way, one agar plates for each microorganism were prepared for studying the activity of standard Streptomycin $(10 \mathrm{mg} / \mathrm{ml})$. For assaying antibacterial activity, plates were incubated at $37^{\circ} \mathrm{C}$ for $24 \mathrm{hr}$. The diameter of zone of inhibition (in $\mathrm{mm}$ ) was recorded.

\section{Antifungal Activity}

The extracts were screened for their antifungal activity in comparison with standard Tetracycline $(10 \mathrm{mg} / \mathrm{ml})$ in -vitro by agar well diffusion method (Indian Pharmocopia, 1996). About 15-20 $\mathrm{ml}$ of the Potato Dextrose Agar (PDA) medium was poured in the sterilized Petridis under aseptic conditions and allowed for solidifying. Then each plate was inoculated with $200 \mu \mathrm{l}$ of $36 \mathrm{~h}$ old fungal culture and was evenly spread with a sterile bent glass rod. A sterile cork borer was then used to make four wells $(8 \mathrm{~mm}$ diameter) for different concentrations of the extract, on each of the plates containing cultures of the different test organisms. The four peripheral wells were loaded with $100 \mu \mathrm{l}$ of pet ether, chloroform, methanol and aqueous plant extracts of the concentration 25,50 and $100 \mathrm{mg} / \mathrm{ml}$ respectively. In the similar way, one agar plates for each microorganism were prepared for studying the activity of standard Tetracyclin $(10 \mathrm{mg} / \mathrm{ml})$. For assaying antibacterial activity, plates were incubated at $37^{\circ} \mathrm{C}$ for $24 \mathrm{hr}$. The diameter of zone of inhibition (in $\mathrm{mm}$ ) was recorded.

\section{Statistical analysis}

The data of all measurements are means from three replications. Data and statistical significance of difference were evaluated with analysis of variance (ANOVA) using SPSS 10.0 package.

\section{Results and Discussion}

Yield of Crude extract: The extraction yield of different solvents varied from $0.6 \%$ to 1.20 and could be ranked from high to low i.e. aqueous $>$ methanol $>$ chloroform $>$ pet-ether extracts (Fig-I). The percentage of extraction yield will increase with the ratio of solvents, temperature and sample extraction. The highest percentage of extraction yield was observed in aqueous extracts of S. aegyptiaca. Similar results are reported by Mukharjee (2002) in leaves of Leucas lavandulaefolia.

Phytochemical analysis: The crude extracts viz., pet-ether, chloroform, methanol and aqueous extracts of whole plant of Salvia aegyptiaca was qualitatively screened for the occurrence of various primary and secondary metabolites by treating with various chemical reagents. The reactions with these reagents have shown the presence or absence of metabolites were recorded in the Table.1. The preliminary screening test revealed that the presence of protein, carbohydrate, lipids and also the presence of various groups of secondary metabolites such alkaloids, phenols, flavonoids, steroids, tannins, terpenoids and resins in all extracts. However the glycosides and tannins were observed only in methanol and aqueous extracts. The saponins were absent in all extracts of the Salvia aegyptiaca. These compounds have significant therapeutic application against human pathogens including bacteria, fungi or virus. In recent years these bioactive components are used in different forms such as infusions, syrups, concoctions, decoctions, 
essential oils, ointments and creams (Sahu, 2014).

Antimicrobial activity: The crude extracts of S. aegyptiaca exhibited in vitro antibacterial activity against Gram positive bacteria of Staphylococcus aureus and Gram negative bacteria of Pseudomonas aeruginosa. As the drug dose increased (25, 50 and $100 \mathrm{mg} /$ well) simultaneously increased the zone of inhibition of the bacterial growth (Table.2). Staphylococcus aureus exhibited considerable sensitivity against methanol $(1.45 \pm 0.08 \mathrm{~mm})$ at $100 \mathrm{mg} / \mathrm{ml}$ concentration followed by chloroform $(0.93 \pm 0.09 \mathrm{~mm})$ and aqueous $(1.2 \pm 0.5 \mathrm{~mm})$ extracts. However pet-ether extract was totally resistant against Staphylococcus aureus. Whereas, Pseudomonas aeruginosa exhibited sensitivity towards the all crude extracts, among methanol extract possess the highest inhibition zone $(1.36 \pm 0.5 \mathrm{~mm})$ at $100 \mathrm{mg} / \mathrm{ml}$ concentration. However the aqueous extract is completely resistant against Pseudomonas aeruginosa. Similarly, Ebrahimabadi (2010) has reported the essential oil and methanol extract of $S$. eremophila showed relatively strong antimicrobial activity against Grampositive and Gram-negative bacteria including E. coli, B. subtilis, Staph. aureus and Staph. epidermis.

Table.1 Metabolites Of Crude Extracts of Salvia aegyptiaca

\begin{tabular}{|c|c|c|c|c|c|}
\hline \multicolumn{2}{|l|}{ Metabolites } & Pet-ether & Chloroform & Methanol & Aqueous \\
\hline \multirow[t]{2}{*}{ Proteins } & Biuret test & + & + & + & + \\
\hline & Hopkin-Cole test & + & + & + & + \\
\hline \multirow[t]{3}{*}{ Carbohydrates } & $\begin{array}{l}\text { Molisch reagent } \\
\text { test }\end{array}$ & + & + & + & + \\
\hline & Benedict's test & + & + & + & + \\
\hline & Fehling's test & + & + & + & + \\
\hline \multirow[t]{2}{*}{ Lipids } & Stain test & + & + & + & + \\
\hline & Saponification test & + & + & + & + \\
\hline \multirow[t]{3}{*}{ Alkaloids } & Mayer's test & + & + & + & + \\
\hline & Wagner's test & + & + & + & + \\
\hline & Dragendroff's test & + & + & + & + \\
\hline \multirow[t]{2}{*}{ Phenols } & Ferric chloride test & + & + & + & + \\
\hline & Ellagic acid test & + & + & + & + \\
\hline \multirow[t]{2}{*}{ Flavonoids } & Pew's test & + & + & + & + \\
\hline & Shinoda test & + & + & + & + \\
\hline Steroids & Salkowski's test & + & + & + & + \\
\hline \multirow[t]{2}{*}{ Glycosides } & Conc. $\mathrm{H}_{2} \mathrm{SO}_{4}$ test & - & - & + & + \\
\hline & Keller killiani test & - & - & + & + \\
\hline Tannins & Gelatin test & - & - & + & + \\
\hline Terpenoids & Conc. $\mathrm{H}_{2} \mathrm{SO}_{4}$ test & + & + & + & + \\
\hline Saponins & Foam test & - & - & - & - \\
\hline Resins & $\begin{array}{l}\text { Copper sulphate } \\
\text { test }\end{array}$ & + & + & + & + \\
\hline
\end{tabular}

Note: '+' Present, '-' Absent 
Table.2 Antibacterial Activity of Various Crude Extracts of Salvia aegyptiaca

\begin{tabular}{|c|c|c|c|c|c|c|}
\hline \multirow[b]{2}{*}{$\begin{array}{l}\text { Name of } \\
\text { Bacteria }\end{array}$} & \multicolumn{6}{|c|}{ Diameter of the Zone of inhibition (mm) } \\
\hline & $\begin{array}{l}\text { Conc. } \\
(\mathrm{mg} / \mathrm{ml})\end{array}$ & $\begin{array}{l}\text { Pet- } \\
\text { ether }\end{array}$ & Chloroform & Methanol & Aqueous & $\begin{array}{l}\text { Streptomycin } \\
10 \mathrm{mg} / \mathrm{ml}\end{array}$ \\
\hline \multirow{3}{*}{$\begin{array}{l}\text { Staphylococcus } \\
\text { aureus }\end{array}$} & 25 & - & - & $0.8 \pm 0.05$ & $0.46 \pm 0.08$ & \multirow{3}{*}{ 5. $0 \pm 0.5$} \\
\hline & 50 & - & - & $1.16 \pm 0.12$ & $0.8 \pm 0.06$ & \\
\hline & 100 & - & $0.93 \pm 0.09$ & $1.45 \pm 0.08$ & $1.2 \pm 0.5$ & \\
\hline \multirow{3}{*}{$\begin{array}{l}\text { Pseudomaonas } \\
\text { aeruginosa }\end{array}$} & 25 & - & $0.8 \pm 0.05$ & $0.83 \pm 0.05$ & - & \multirow[b]{3}{*}{$7.0 \pm 0.2$} \\
\hline & 50 & $0.63 \pm 0.02$ & $1.11 \pm 0.42$ & $1.0 \pm 0.82$ & - & \\
\hline & 100 & $0.93 \pm 0.05$ & $1.23 \pm 0.5$ & $1.36 \pm 0.5$ & - & \\
\hline
\end{tabular}

Each value is expressed as mean \pm S.D. $(n=3)$ and statistically significant $\mathrm{P}<0.05$

Table.3 Antifungal Activity of Various Crude Extracts of Salvia aegyptiaca

\begin{tabular}{|c|c|c|c|c|c|c|}
\hline \multirow[b]{2}{*}{$\begin{array}{c}\text { Name of } \\
\text { fungi }\end{array}$} & \multicolumn{6}{|c|}{ Diameter of the Zone of inhibition (mm) } \\
\hline & $\begin{array}{l}\text { Conc. } \\
\text { (mg/ml) }\end{array}$ & $\begin{array}{l}\text { Pet- } \\
\text { ether }\end{array}$ & Chloroform & Methanol & Aqueous & $\begin{array}{l}\text { Tetracycline } \\
10 \mathrm{mg} / \mathrm{ml}\end{array}$ \\
\hline \multirow{3}{*}{$\begin{array}{l}\text { Aspergillus } \\
\text { niger }\end{array}$} & 25 & - & - & - & - & \multirow{3}{*}{$4.0 \pm 0.5$} \\
\hline & 50 & $0.36 \pm 0.07$ & $0.60 \pm 0.04$ & $042 \pm 0.05$ & $0.6 \pm 0.12$ & \\
\hline & 100 & $0.43 \pm 0.02$ & $0.76 \pm 0.08$ & $0.70 \pm 0.05$ & $1.36 \pm 0.5$ & \\
\hline \multirow{3}{*}{$\begin{array}{l}\text { Aspergillus } \\
\text { flavus }\end{array}$} & 25 & $0.63 \pm 0.13$ & - & $0.56 \pm 0.06$ & - & \multirow{3}{*}{$6.0 \pm 0.2$} \\
\hline & 50 & $1.13 \pm 0.15$ & $0.70 \pm 0.5$ & $0.63 \pm 0.05$ & $1.53 \pm 0.6$ & \\
\hline & 100 & $1.40 \pm 0.5$ & $1.2 \pm 0.2$ & $1.10 \pm 0.4$ & $3.10 \pm 0.8$ & \\
\hline
\end{tabular}

Fig.1 Yield of various crude extract of Salvia aegyptiaca L.

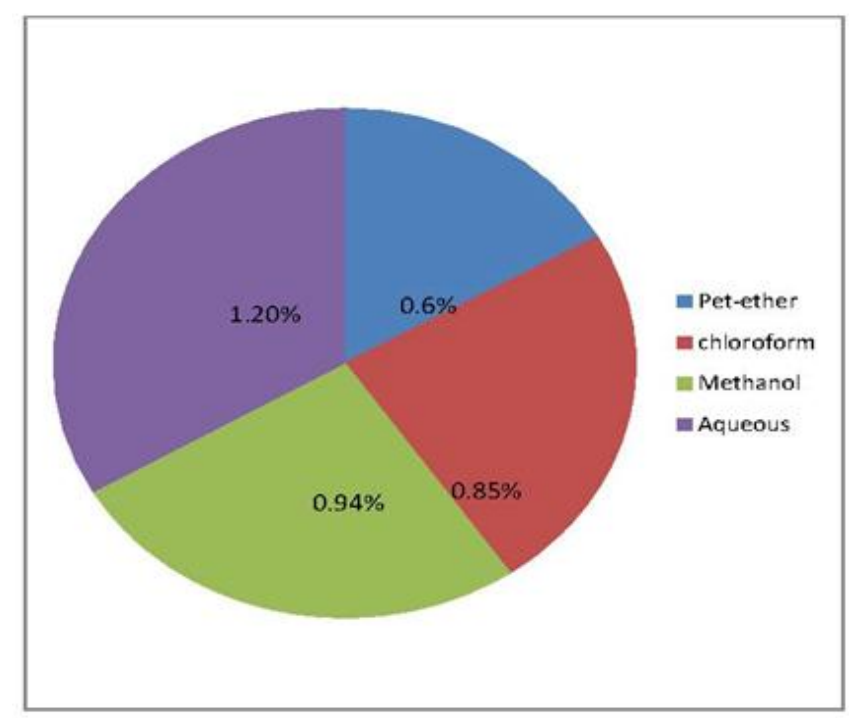

Of all the bacteria tested the Gram-positive bacteria were slightly more susceptible to the extracts than the Gram-negative bacteria, therefore the present results are in agreement with earlier reports (Jigna and Sumitra, 2006; Dougharia and Manzara, 2008). The crude 
extracts of $S$. aegyptiaca exhibited in vitro antifungal activity against Aspergillus niger and Aspergillus flavus. As the drug dose increased (25, 50 and $100 \mathrm{mg} /$ well $)$ simultaneously increased the zone of inhibition of the fungal growth (Table.3). The aqueous extract shows highest antifungal activity on both Aspergillus niger and Aspergillus flavus, among the maximum inhibition growth was observed in Aspergillus flavus $(3.10 \pm 0.8 \mathrm{~mm})$ compared to Aspergillus niger $\quad(1.36 \pm 0.5 \mathrm{~mm})$ at $100 \mathrm{mg} / \mathrm{ml}$ concentration. Abdulhamida et al., (2013) have observed the most sensitive fungus to the esstenial oil was Aspergillus flavus compared to Aspergillus niger in Salvia fruticosa. It was interesting to note that bacteria was more sensitive to methanol extract whereas, fungi was more sensitive towards aqueous extracts .The difference in the observed activities of the various extract may be due to varying degree of solubility of active constituents in the solvents used. It has been documented that different solvents have diverse solubility capacities for different phytoconstituents (Majorie, 1999). The antimicrobial activity of various crude extracts of $S$. aegyptiaca shows that the maximum inhibition zone in methanol extract against Pseudomonas aeruginosa $(1.36 \pm 0.5 \mathrm{~mm})$ and aqueous extract against Aspergillus flavus $(3.10 \pm 0.8 \mathrm{~mm})$. Overall, fungi were more sensitive than the bacterial strains in Salvia aegyptiaca. Further investigation of activity against a wider range of pathogens, identification and purification of active chemical constituents and toxicological investigation of plant extracts should be carried out with a view to developing novel drugs for human consumption.

\section{Acknowledgements}

The authors are thankful to the Dr. Babu R.L. Coordinator, Department of Botany, Karnataka State Women's University
Vijayapura, India for providing the laboratory facilities.

\section{References}

Abdulhamid A., Giweli, Ana M. Dzamici, Marina Sokovic, Ristic M.S. 2013. The chemical composition, antimicrobial and antioxidant activites of the essential oil of Salvia fruticosa growing wild in Libya, Arch. Biol. Sci.,Belgrade, 65(1): 321-329.

Ali and Aboud. 2010. Antimicrobial Activities of Aqueous and Methanolic extracts from Salvia officinalis and Salix acmophylla Used in the treatment of wound infection isolates. Ibn Al-Haitham J. for Pure and Appl. Sci., 23(3):1-13.

Al-Yousuf M.H., Bashir A.K., Ali B.H., Tanira M.O. and Blunden G. 2002. Some effects of Salvia aegyptiaca L. on the central nervous system in mice. $J$. Ethnopharmacol., 81: 121-127.

Bagci, E. and Koçaka, A., 2007. Study on the analysis and evaluation of essential oils of two Salvia (S.ceratophylla L., S. aethiopis L.) species. Sci. Eng. J. Firat Univ., 19(4): 435-442.

Cooke, T. 1906. Lamiaceae. In The Flora of the Presidency of Bombay. Taylor and Francis, London.2:473-475.

Dougharia, J.H. and Manzara, S. 2008. In vitro antibacterial activity of crude leaf extracts of Mangifera indica Linn. Afr. J. Microbiol. Res., 2: 67-72.

Ebrahimabadi, A.H., Mazoochi, A., Kashi, F.J., Djafari-Bidgoli, Z. and Batooli, H. 2010. Essential oil composition and antioxidant and antimicrobial properties of the aerial parts of Salvia eremophila Boiss. Iran. Food Chem. Toxicol., 48: 1371-1376.

Firdous, A.J., Islam, S.N.L.M and Faruque, A.B.M. 1990. Antimicrobial activity of the leaves of Adhatoda vasica, Calatropis gigantium, Nerium odoratum and Ocimum sanctum, J. Bot., 227-230.

Gibbs, R.D. 1974. Chemotaxonomy of flowering plants. McGill Queen's University, Press Monteral and London. 
Harborne, J.B. 1998. Phytochemical methods, A guide to modern techniques of plant analysis $3^{\text {rd }}$ Edn. Chapman and Hall, Madras.

Indian Pharmacopoeia. 1996. Government of India, Ministry of Health and Family Welfare Published by the Controller of Publications, Delhi, 11: Pp 218.

Jigna, P. and Sumitra, C. 2006. In-vitro antimicrobial activities of extracts of Launaea procumbens Roxb.(Labiateae), Vitis vinifera L. (Vitaceae) and Cyperus rotundus L. (Cyperaceae). Afri. J. Biomed. Res., 9(2): 89-93

Majorie, M.C. 1999. Plant Product as Antimicrobial Activity Plant Product as Antimicrobial agents. Clin. Microbial. Rev., 12(4): 564-582.

Mukherjee, K., Saha, B.P. and Putok, K.M. 2002. Psychopharmacological profiles of C. cajan. Rees. Phytotherapy Res., 16: 696-699.

Nurcan Erbil and Metin Digrak. 2015. Total phenolic and Flavonoid Contents, Antimicrobial and Antioxidant Properties of Salvia verticillata $\mathrm{L}$. var. amasiaca and Salvia microstegia Boiss \& Bal from Turkish Flora. J. Microbiol. Antimicrobial, 1(1): 23-29.

Omidreza Firuzi, Ramin Miri, Mojtaba Asdollahi, Saba Eslami and Amir Reza Jassbi 2013.Cytotoxic, Antioxidant and Antimicrobial Activities and Phenolic Contents of Eleven Salvia Species from Iran, Iranian J. Pharmaceutical Res., 12(4): 801- 806.

Sahu, M., Vermaand, D. and Harris, K.K. 2014. Phytochemical analysis of the leaf, stem and seed extracts of cajanus cajan L (dicotyledoneae: fabaceae), World $J$.
Pharmacy And Pharmaceutical Sci.,, 3(8): 694- 733.

Sadasivam, S. and Manickam, A. 1992. Biochemical methods for agricultural sciences, Wiley Eastern Ltd., Ansari Road, Daryaganj, New Delhi, Pp 1-200.

Salem, A.B. 2004. Chemical constituents of Salvia aegyptica. J. King Abdulaziz Univ., 16: 33- 39.

Raghunathan, K. 1976. Pharmacopoeial standards for Ayurvedic formulations. Central council for Research in Indian Medicine and Homeopathy, E-25, Defense colony, New Delhi, Pp 378.

Rizk, A., El-Ghazaly, G. 1995. Salvia aegyptiaca L. Medicinal and poisonous plants of Qatar. Sci. Appl. Res. Centre, University of Qatar, King Print of Richmond; 1995: 140-1.

Tanaka, J.C.A., da Silva, C.C., de Oliveira, A.J.B., Nakamura, C.V., Dias Filho, B.P. 2006. Antibacterial activity of indole alkaloids from Aspidosperma ramiflorum. Brazalian J. Med. Biol. Res., 39(3): 387391.

Tepe, B., Eminagaoglu, O., Akpulat, H.A., Aydin, E. 2007. Antioxidant Potentials and rosmarinic acid levels of the methanolic extracts of Salvia verticillata (L.) subsp. verticillata and S. verticillata (L.) subsp. amasiaca (Freyn \& Bornm.), Bornm. Food Chem., 100: 985-989.

Usha, S., Joshi, P. and Sharma, H.P. 1984. Pharmacognostic studies on Atemisia scoparia Waldst and Kit. Proceedings of Indian Academy of Sci., (Plant Sci.,), 93(2): 151-164.

\section{How to cite this article:}

Pratima, H., and Veenashri Policepatil. 2017. Phytochemical Screening and Antimicrobial Activity of Various Extracts of Salvia aegyptiaca L. Int.J.Curr.Microbiol.App.Sci. 6(1): 600608. doi: http://dx.doi.org/10.20546/ijcmas.2017.601.073 